\title{
Conservation and Management of Forest Resources in India: Ancient and Current Perspectives
}

\author{
M. S. Umesh Babu, Sunil Nautiyal \\ Centre for Ecological Economics and Natural Resources, Institute for Social and Economic Change, Bangalore, \\ India \\ Email: nautiyal sunil@rediffmail.com
}

Received 4 March 2015; accepted 9 April 2015; published 13 April 2015

Copyright @ 2015 by authors and Scientific Research Publishing Inc.

This work is licensed under the Creative Commons Attribution International License (CC BY). http://creativecommons.org/licenses/by/4.0/

cC) (i) Open Access

\section{Abstract}

This paper brings out the issues related to natural resource exists, management and erosion right from the ancient to modern era. The natural resource such as forests and forest products were found as a basic source of survival for living organisms during the initial period. Later, the natural resources started degrading slowly and steadily due to increased human activities. In the beginning, natural resources were the primary assets for the growth of agriculture, industry, urbanization etc. Subsequently, increased anthropogenic activities started degrading the forest cover on a large scale through extending the agricultural land scape and other developmental activities in the country. The importance of traditional knowledge regarding resource conservation, protection of sacred grooves, endangered species etc. started declining in modern India. Innovativeness and policy framework for resource conservation and utilization became unfriendly in addition to gradual decline of community management. The key findings of the study point to major gaps existing such as between line departments and institutions in the promotion and management of forests, human welfare, agriculture, animal husbandry etc. Moreover, people tend to be more inclined towards the utilization of natural resources rather than conservation. From an observational and practical point of view, the natural resource has been declining rapidly in India. Therefore, this study strongly suggests that a due attention be directed towards developing people-friendly and environment friendly conservation strategies.

\section{Keywords}

Theory, Practice, Natural Resources, Approaches, Management 


\section{Introduction}

The management of Natural Resources is a scientific approach for utilization and conservation of land, water bodies, soil systems, plants and animals to enable the people to fulfill the requirement so that along with the present generation the future generations would also be benefited. Therefore, the management of natural resources is combination of scientific and technical understanding of the same. This study mainly focuses on conservation and management of forest resources in India.

Considering that the indigenous communities happen to be the holders and carriers of traditional ecological knowledge and wisdom regarding the use and management of natural resources, their active participation in the various biodiversity programmes is absolutely essential to ensuring their sustainability and cost-effectiveness. In other words, it is important that their prior consultation, participation, and consent procedures (communication with each other) are ensured for implementing such programmes mainly due to the fact that the approach of indigenous communities towards assessing the value of natural resources (both in terms of conservation and utilization) is quite unique as compared to the present day conservation and economists [1].

\section{A Brief History}

Conservation Principles as Explained in Atharva Veda: Atharva Veda (12.1.11) hymns believed to have been composed at around $800 \mathrm{BC}$, somewhere amidst deep forests, read: "O Earth! Pleasant be thy hills, snow-clad mountains and forests; O numerous coloured, firm and protected Earth! On this earth I stand, undefeated, unslain, unhurt."

Utilization and Regeneration Principles: Another hymn from Atharva Veda (12.1.35) reads: "Whatever I dig out from you, O Earth! May that has quick regeneration again; may we not damage the vital habitat and heart."

About 10,000 years ago, people started adopting an agrarian way of life and over time this new type of livelihood system spread everywhere with the population beginning to expand faster than ever before. In the course of time, a sedentary agricultural life led to the evolution of villages, cities and eventually states all of which were highly dependent on fresh water resources ${ }^{1}$.

As per the Vedic tradition village all the villages came under three main categories, namely, Mahavan, Tapovan and Shrivan ${ }^{2}$. From third century AD onwards, town-building began in the northern regions of India with ecology and the nature of human and animal habitat changing over period; for instance, the dry lands, where people lived by rearing animal herding, became lands of great scarcity and danger whenever rains failed, with wolves and thieves attacking people. Long before the times referred to by the Sanskrit texts, wild animals were a major source of meat across various places of the Harappan civilization. However, in certain parts of western India, seeds were found mostly in ancient houses. While people hunted a wide variety of wild animals, they reared only a few varieties. It is significant to note that the use of iron tools and fire often referred to in the ancient Sanskrit texts is considered as being mainly responsible for replacing forests with farmlands, and nature with culture $^{2}$. Thus, approaches towards NRM can be explained, in terms of historic, functional and futuristic perspectives (Table 1 ).

Natural resources such as land, water bodies, biodiversity and genetic resources, biomass resources, forests, livestock and fisheries-are the basic sources of human survival and prosperity. However, it is observed that they have been steadily degrading since 5000 B.C and the unprecedented pace of their erosion is the root cause for the present environmental uncertainties. The over-exploitation of natural resources in the context of an ever growing population has resulted in various problems such as land degradation, vegetation loss, pollution and so on. Such problems need to be addressed seriously using traditional knowledge, a proven treasure for natural resource management, as the main basis. One of the major concerns in this endeavor is to rehabilitate the degraded and vulnerable lands. In this respect, an account of the existing historical and traditional aspects of natural resource management, particularly forest resources is presented here in the Indian context.

\section{Ancient Viewpoint}

According to study [2], Indo-Aryans (circa 3000 B.C) were occupying the country as an Indian frontier during

${ }^{1}$ http://www.iwawaterwiki.org/xwiki/bin/view/Articles/BRIEFHISTORYOFWATERANDHEALTHFROMANCIENTCIVILIZATIONSTO MODERNTIMES. Accessed: 19.11.2011.

${ }^{2}$ http://www.indiaenvironmentportal.org.in/files/Forestry\%20in\%20ancient\%20India.pdf. Accessed: 19.11.2011. 
Table 1. NRM from different perspectives-historical, functional and futuristic-and their relation to traditional conservation methods.

\begin{tabular}{|c|c|c|c|}
\hline $\begin{array}{c}\text { Attributes of Natural } \\
\text { Resource Management } \\
\text { (NRM) }\end{array}$ & Historical Perspective & Functional Perspective & Futuristic Perspective \\
\hline $\begin{array}{l}\text { Traditional Ecological } \\
\text { Knowledge (TEK) } \\
\text { regarding NRM }\end{array}$ & Was given a high importance. & $\begin{array}{l}\text { Apart from TEK, certain new interventions } \\
\text { have been made for conservation of natural } \\
\text { resources. However, TEK has started losing } \\
\text { its prime role in the management of natural } \\
\text { resources across various regions. }\end{array}$ & $\begin{array}{l}\text { TEK is in jeopardy, thus needs } \\
\text { to be given a high priority for } \\
\text { proper documentation. }\end{array}$ \\
\hline $\begin{array}{l}\text { Conservation and } \\
\text { Management of } \\
\text { Natural Resources }\end{array}$ & $\begin{array}{l}\text { The resources were used for } \\
\text { fulfilling the basic needs on } \\
\text { a sustainable basis. }\end{array}$ & $\begin{array}{l}\text { Resource exploitation is high and as a } \\
\text { result, resources are depleting very fast. }\end{array}$ & $\begin{array}{l}\text { Need to rethink from the } \\
\text { perspective of growing population } \\
\text { on the one hand, and the declining } \\
\text { resources on the other. }\end{array}$ \\
\hline $\begin{array}{l}\text { Dependence on } \\
\text { Natural Resources }\end{array}$ & $\begin{array}{l}\text { Sustainable utilization for only } \\
\text { meeting the basic requirements. }\end{array}$ & $\begin{array}{l}\text { Increased for various needs without } \\
\text { thinking needs of the future generation. }\end{array}$ & $\begin{array}{l}\text { Depends on the availability of } \\
\text { various ecological resources }\end{array}$ \\
\hline $\begin{array}{l}\text { Supply and Demand for } \\
\text { Natural Resources }\end{array}$ & It was on a sustainable basis. & Not in an equilibrium. & $\begin{array}{l}\text { Lesser chances of a sustainable } \\
\text { ecological resource flow, if the } \\
\text { current trend were to continue. }\end{array}$ \\
\hline $\begin{array}{l}\text { Innovativeness in } \\
\text { Resource conservation }\end{array}$ & $\begin{array}{l}\text { Through the process of trial } \\
\text { and error with TEK as the } \\
\text { main basis. }\end{array}$ & $\begin{array}{l}\text { Various innovations have been made, but } \\
\text { a majority of them are not being practiced. }\end{array}$ & $\begin{array}{l}\text { There is a need for a proper } \\
\text { evaluation of all the innovations } \\
\text { made so far with appropriate } \\
\text { strategies have to be devised for } \\
\text { resource utilization and } \\
\text { conservation for future generations. }\end{array}$ \\
\hline $\begin{array}{l}\text { Role of institutions in } \\
\text { resource management }\end{array}$ & Community participation & $\begin{array}{l}\text { Institutions have been developed without } \\
\text { a proper thought given to most of the cases. }\end{array}$ & $\begin{array}{l}\text { Has to play a major role within } \\
\text { an integrated framework. }\end{array}$ \\
\hline $\begin{array}{l}\text { Policy inventions in } \\
\text { resource utilization }\end{array}$ & $\begin{array}{l}\text { Various traditional ecological } \\
\text { methods introduced for } \\
\text { resource utilization. }\end{array}$ & $\begin{array}{l}\text { The policy has become the main tool } \\
\text { for resource utilization. }\end{array}$ & $\begin{array}{l}\text { Existing policies need to be } \\
\text { revisited for proper implementation. }\end{array}$ \\
\hline
\end{tabular}

the pre-Indian age. The Aryans were a nomadic agricultural tribe quite different from their Iranian brethren peculiar to the Indo-Aryans of the Rig-Veda. The Indian civilization evolved around the five river basins namely the Indus Valley, Sind and Western Rajputana, Gangetic provinces \& delta, Narmada and Peninsula. The Aryans were located around the Hindu Kush and Sutlej basins/regions. Although rich in soils, the flourishing communities were still primitive with respect to their agricultural practices their period approximately lasted from 20001500 B.C.

Certain scientific inquiries required for a proper understating of the Vedas and the Vedic rituals [2], can be located in the elaboration of Vedangas, namely 1) Kalpa which includes geometry so far as it is applied to the construction of sacrificial altars; 2) Siksha or phonetics; 3) Chandas or meter; 4) Vyakarana or grammar; 5) Nirukta or study of words; 6) Jyotisha or astrology. These Vedangas find a brief treatment in the Brahmanas or Upanishads acquiring a necessary scientific cast relevant even to the present age.

Moreover, Pali literature is undoubtedly the most important source with regard to the topography ancient Indian topography. Similarly the great literature of the early Buddhist period is the main source of the historical and geographical information about ancient India, followed by Jaina and Brahmanical sources to a certain extent. For later periods, we have abundant geographical and archaeological sources and literary sources, as well as the accounts of the classical geographers and the travelogues of the Chinese pilgrims, while the geographic information contained in Pali and Sanskrit, Buddhist literature is considerably important [3].

Grammarian Panini refers to this period while bringing the history of South India into touch with that of the North. If the great epic Ramayana, could be trusted, the great forest extended up to the Pampa Saras on the north bank of the Tungabhadra near modern Hampi, though the Saras (or Tank) must have been forgotten under the name as the author of the Tamil Ramayana refers to it as Pampanadi. The advent of Agastia introduced the reclamation of the jungle into arable land, and was reputed author of the first Tamil grammar [2]. 
According to study [3] India was bounded on the north by the stupendous Himalayan mountain ranges and on the other three sides by the mighty beas and the ocean, constituting a distinct geographical unit. The sheer vastness of the country with its infinite variety of fauna and flora, races and languages, religions and cultures justly lent itself to be called a great subcontinent. The word "India" is derived from the river Sindhu. The Chinese also knew the ancient name of India as Shin-tnh or Sindbu. It should, however, be noted that the Vedic "Sapta Sindhavat" and the Persian "Hi(n)du" corresponded only to a particular geographical area lying to the north-west of India.

\subsection{Forest Resources as Explained in Epic Ramayana (300 BC-200 AD)}

In Valmiki Ramayana, two Sanskrit words viz., "Vana” and "Aranya” are used while referring to forests. The term "Vana" is used to denote sub-forestation, a kind of cultivated forest with a clustering of desirable plants, conserved for a purpose. As the legend goes, Rama, Sita and Lakshmana had settled down in Chitrakoota forest because of its rich biodiversity. Strangely, Lanka supported two kinds of forests-the natural woodland of its own and the cultivated forest of the Royal Majesty. The Indian forests are enigmatically known and described as the land of "glowing" also rich in medicinal plants.

The narrative style of all these forest types is supposed to evoke four predominant sentiments or "rasas" (i.e. moods) such as "Santa” (Tranquility), "Madhura” (Sweetness), "Roudra” (Fury) and "Bibhatsa” (repulsion) ${ }^{3}$. The example of importance of tree is mentioned in Box 1.

\subsection{Forest Destruction in Ancient India}

According to study [4], the destruction of forests for valuable wood on the plains causes many of the hills lose their forest cover resulting in the rainfall rushing quickly down their bare slopes which in turn, prevents the growth of new trees. Further the cultivation of potato crop, introduced from England, leads then to a further destruction of trees. Those living on the hill clear their potato fields now and then by burning a ring round the sterns of the great trees, while converting the mountain sides into terraces. As a result within a few years, the barks and leaves would drop off the branches, with the forest standing bleached and ruined. Some of the trees would rot on the ground, like giants fallen in a confused fight, while others still remaining upright with white trunks and skeleton-like arms. In the ranks, green potato crop mark the spot where forest has been slain and buried. Several of the ruder hill tribes follow an even more wasteful mode of tillage. Bereft of either ploughs or cattle, they burn down the jungle, exhausting the soil by a quick succession of crops, raised by a within a year or two, the whole settlement moves on to a fresh patch of jungle, while repeating the same process.

There is a little-known legend related to Vijayadashami festival associated with Mahabharata. The Pandavas underwent a period of exile, i.e., 12 years of dwelling in the forest followed by a year of incognito exile. It is said that the particular Shami tree chosen by the Pandavas stood inside a cremation ground. The Pandavas wrapped their weapons in a white cloth and concealed the same on the same tree, making the weapons look like a dead body. Virata Parva, Chapter 5 of the Mahabharata epic, mentions that on the southern bank of River Yamuna in Viratanagara, Arjuna hide his bow "Gandiva” on a Shami tree. Meanwhile, the Kauravas had invaded that area, suspecting that the Pandavas resided there. Upon completing their exile period, the Pandavas headed straight to the battle field, and won the contest comprehensively. Even to this day, across various parts of Indian, people exchange Shami leaves on Vijayadashami, while wishing each other success in their own ventures and efforts.

Box 1. The legend of Shami tree (Prosopis Cineraria).

3http://gattflysnest.blogspot.in/2010/05/biodiversity-in-epic-ramayana 19.html. Accessed: 10.11.2011.

${ }^{4}$ http://en.wikipedia.org/wiki/Flora_of_the_Indian_epic_period. Accessed: 15.12.2011. 
Habitat destruction is identified as the main threat to biodiversity conservation. Under diverse natural conditions, over a billion people in rural and urban areas live in harmony under a democratic system in India. However, their pressing needs of food, fibre, shelter, fuel and fodder combined with a compelling need for economic development exert an enormous pressure on the natural resources and the resultant loss and fragmentation of natural habitats affect all animal and plant species. Therefore, it is imperative to prevent not only any further habitat loss in the immediate future, but also to restore a substantial fraction of the wilderness that has been lost in the past. Various plant and animal species are on the decline largely due to habitat fragmentation and overexploitation, e.g. Habitats of Great Indian Bustard in Madhya Pradesh, Gujarat and Rajasthan, and the Lion-tailed Macaque in the Western Ghats [5].

The predominant causes behind the dwindling of forest wealth are over-exploitation, overgrazing, illegal encroachments, unsustainable practices, forest fires, and environment-unfriendly development projects in the forest areas. The collection of forest products including fuel wood, timber etc, are observed to be much beyond the regenerative capacity of our forests [7].

The two main direct threats to biodiversity conservation are habitat degradation and loss of biodiversity for example refer Box 2. Pollution and invasive species are also significant threats whose adverse effects are clearly discernible in relation to freshwater ecosystems. The biodiversity loss can be attributed to economic growth and increasing consumption, poverty, capacity constraints, lack of environmental safeguards, lack of comprehensive land-use policies and plans, undervaluation, lack of grassroots level support for conservation, and global climate change.

\subsection{Degradation of Forest Resources}

An ever expanding population pressure, poverty and a weak institutional framework have often been viewed as the predominant causes underlying deforestation and degradation in the developing and developed countries Table 2 and Table 3. An ever growing human and livestock population and the dependence on the forest products essential for sustenance and development invariably exert enormous pressures on the forest resources like fuel wood, fodder, timber, paper, etc., which, in turn, trigger an irreversible deforestation process. The over exploitation of forest resources as compared to its incremental and regenerative capacities tends to escalate the forest

The ancient Sanskrit poets speak of the southern tableland as buried under forest with sdl, ebony, sissu, teak, and other great tree spe-
cies that are still found in abundance. The Ghats, in particular, are endowed with a magnificent vegetation cover. However, the in-
creased cultivation of crops has driven the jungle to the fields of wheat, and many other kinds of smaller grain or millets, tobacco,
cotton, sugar-cane, and pulses, which are spread over the open country. The black soil of Southern India is proverbial for its fertility as
also the lowlands between the Ghats and the sea rival including even Lower Bengal with their fruit-bearing palms, rice harvests, and
rich succession of crops. The tableland is, however, very susceptible to droughts; and the people have devised a varied system of irri-
gation, (depending on the region) such as wells, tanks, artificial lakes (formed by damming up the mouths of river valleys), etc. They
thus store rain water during a few months of the northern and southern monsoons.

(Source: [4]).

Box 2. A scenario of forest resources in India.

Table 2. Forest cover across the World from 1990-2010.

\begin{tabular}{ccccc}
\hline \multirow{2}{*}{ Region } & \multicolumn{3}{c}{ Total forest cover (in MHa) } & \multirow{2}{*}{ Change (in MHa) } \\
\cline { 2 - 3 } & 1990 & 2000 & 2010 & -75 \\
Africa & 749 & 709 & 674 & 17 \\
Asia & 576 & 570 & 593 & 16 \\
Europe & 989 & 998 & 1005 & -3 \\
North and Central America & 708 & 705 & 705 & -8 \\
Oceania & 199 & 198 & 191 & -82 \\
South America & 946 & 904 & 864 & -135 \\
\hline World & 4168 & 4085 & 4033 & \\
\hline
\end{tabular}

Source: http://www.earth-policy.org/indicators/C56/forests_2012 (Accessed 19.03.2015). 
Table 3. Indicative estimation of species loss due to deforestation across the world.

\begin{tabular}{|c|c|c|c|c|c|}
\hline \multirow{2}{*}{ Ecological zone } & \multicolumn{2}{|c|}{ Forest cover area (in MHa) } & \multirow{2}{*}{$\begin{array}{c}\text { Deforestation rate } \\
\text { (in MHa) } \\
1981-90\end{array}$} & \multirow{2}{*}{$\begin{array}{c}\text { Relative species richness } \\
\text { (Species number) }\end{array}$} & \multirow{2}{*}{$\begin{array}{c}\text { Indicative species } \\
\text { loss (\% loss) }\end{array}$} \\
\hline & 1980 & 1990 & & & \\
\hline \multicolumn{6}{|c|}{ Africa } \\
\hline Tropical rain forest & 91 & 87 & 4.7 & 30700 & 2.0 \\
\hline Moist deciduous forest & 274 & 251 & 22.5 & 13000 & 2.5 \\
\hline Dry and very dry zone & 162 & 151 & 10.8 & 1900 & 1.0 \\
\hline Upland formations & 38 & 35 & 2.9 & 12300 & 2.5 \\
\hline \multicolumn{6}{|c|}{ Asia and Pacific } \\
\hline Tropical rain forest & 199 & 177 & 21.6 & 40400 & 4.3 \\
\hline Moist deciduous forest & 48 & 42 & 6.6 & 7600 & 4.3 \\
\hline Dry and very dry zone & 46 & 41 & 4.7 & 1600 & 1.6 \\
\hline Upland formations & 53 & 47 & 5.8 & 13500 & 3.8 \\
\hline \multicolumn{6}{|c|}{ Latin America and Caribbean } \\
\hline Tropical rain forest & 474 & 454 & 19.4 & 57900 & 1.6 \\
\hline Moist deciduous forest & 326 & 294 & 31.8 & 13700 & 3.0 \\
\hline Dry and very dry zone & 52 & 46 & 6.2 & 1600 & 1.9 \\
\hline Upland formations & 138 & 122 & 16.2 & 18400 & 4.0 \\
\hline
\end{tabular}

Source: http://www.ciesin.columbia.edu/docs/002-471/002-471.html (Accessed 19.03.2015).

depletion and degradation process Table 3. At present the human population exceeded 7 billion which is growing every second. The sheer force of our population where the human species is the dominant factor affecting land, air, water, soil, and species. Figure 1 depicts the relationship between human population and extinction of species between 1800 and 2010 [6]. In fact, an excessive deforestation has impacted not only the local environment, but also the global environment as also the socio-economic and development processes in the developing countries as forests generate a lot of employment opportunities in the primary, secondary, and tertiary sectors besides being a source of subsistence for the poorest of poor in the agricultural economies [7].

Population-driven pressures on croplands, pasturelands and forest lands coupled with rural poverty have triggered a massive migration to urban and industrial centres for wage employment. Further, the pace of urbanization has always been faster than the pace of population growth in India. More importantly, the process of politicization has always been more pronounced than urbanization, since the 1980s [7] become negative growth towards forest resource conservation.

\subsection{Knowledge Dissemination}

Local Ecological Knowledge based on prolonged observations and experiences has evolved over time through oral transfer down the generations. As per the understanding from FGD, farmers need to apply scientific knowledge of resource conservation. Based on the discussion, the traditional knowledge has been declining not only from generation to generation but also is not being transferred effectively. The scientist has to focus on capturing the declining knowledge to link with scientific knowledge. Such initiatives can certainly benefit the societies in the coming days. The changes in the developmental policies and acts also do have negative implications for the traditional system besides being unfavorable to medicinal plants. For example, tribal express that the regeneration of medicinal plants is not taking place in their native places and that their diversity is also declining. This shows the lack of coordination between the local communities and the government while framing policies or rules for conservation. It would be better if researchers could involve tribal people as partners in natural resource conservation rather than just as informers in their studies. 


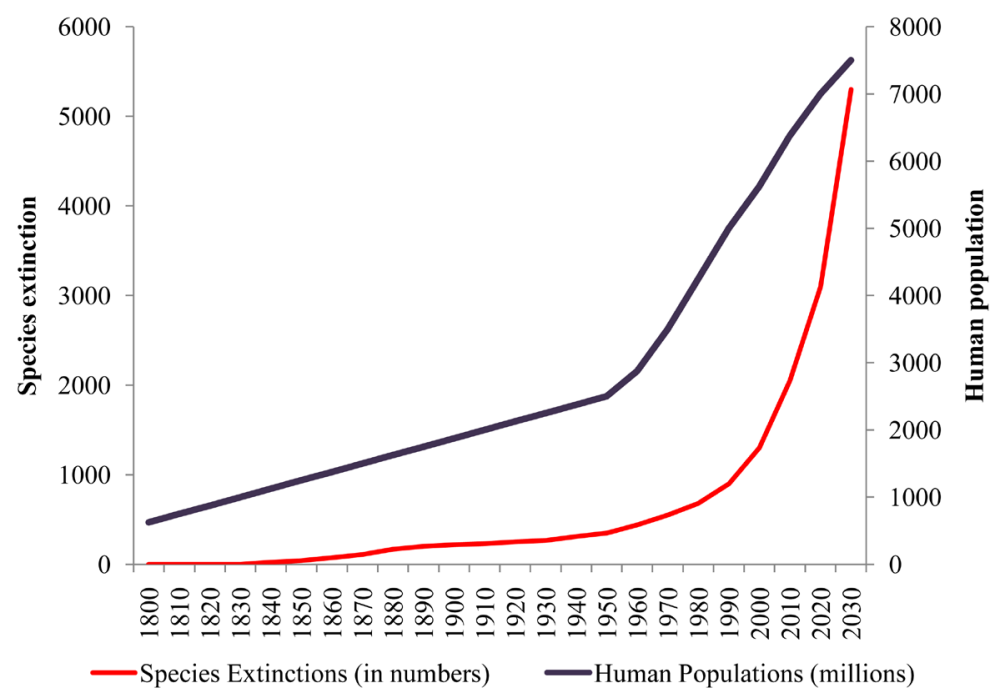

Source: Redrawn from Glikson, A. (2012) [6]. Is another mass extinction event on the way? The Conservation.

Figure 1. Rise in human population and extinction of species between 1800 and 2030.

\subsection{Sacred Groves in India}

The sacred groves dedicated to local deities or ancestral spirits are protected by local communities through social norms and taboos that incorporate spiritual and ecological values. Preserved over many generations, sacred groves represent native vegetation in a natural or near-natural state rich in biodiversity and harbour many rare species of plants and animals. However, the forces of modernization are depleting these sacred groves, weakening the traditional institutions that protect them. Fortunately, thousands of sacred groves still remain intact mainly because many villages continue to observe traditional practices. Most of the sacred groves in India are associated with almost 40,000 endogamous groups within the Hindu caste system and other major religions such as Buddhism and Islam and traditional tribal groups. However, to date, there has been no comprehensive survey of sacred groves conducted in India, and as such, their exact number and the area covered under them are unknown. Nevertheless studies have found 13,720 sacred groves reported across various regions of the country. The studies inform us that the number of sacred groves in India is likely to be between 100,000 and 150,000 .

\subsection{Sacred Trees as Part of Resource Conservation}

According to Hindu mythology, the 14 jewels (fourteen precious objects) which emerged from the depths of the sea (they vary according to the texts) included: horse Uchchaihshravas (symbol of sovereignty), white elephant Airavata (symbol of royalty), throne (symbol of kingship and power), fire (symbol of life), Tulsi plant (representing physician Dhanvantari), chariot, goddess Lakshmi (bestower of abundance) Parijata tree (divine tree), Surabhi (cow), Soma (intoxicating juice derived from sacred plants), Varuna (the sea god), precious stones, tree of life, divine damsels and A lakshmi, goddess of misfortune etc.

Trees being nature's major processors of solar energy besides yielding flowers, fruits, wood and medicine, essential for our existence, are worshipped by Hindus with a deep sense of gratitude and reverence. Many believe that they are conscious like humans and feel pleasure and pain. The Indian sages and seers have eulogized the significance of asvattha or peepal (Ficus religiosa), gular (Ficus glomerata), neem (Azadirachta indica), bel (Aegle marmelos), barged or banyan (Ficus bengalensis), Asoka (Sereca indica), Emile (Phyllanthus emblica), Arjuna (Terminalia Arjuna) and many other tree species which had acquired social and religious sanctity in the ancient times. Due to their ecological value and efficacious properties, trees continue to be used in the religious and social ceremonies by Hindus (for example, see Box 3 and Table 4).

\footnotetext{
${ }^{5}$ http://www.sacredland.org/sacred-groves-of-india/. Accessed: 05.01.2012.
} 
Folio from Baramasa (12 months of the year) set. Bundi School, 1675-1700 A.D.

Fairs and festivals are important parts of Indian life. There are many vratas (observations) and festivals related to natural forces. Teej is one of them. Teej is celebrated at the onset of monsoon in the month of July-August. On this occasion, women, dressed colorfully, carry the image of Goddess Parvati in a procession to the outskirts of a village or town. They spend the whole day in the company of nature playing, singing, dancing and swinging. At some places, neem, a (useful medicinal tree) and Banyan are also worshipped.

Box 3. Month of sravana (rainy season-July-August) ${ }^{6}$.

Table 4. List of trees conserved and worshipped through festivals and vratas in India?.

\begin{tabular}{|c|c|c|}
\hline Name of the Tree & Related Festival or Vrata & Time of Celebration and Rituals \\
\hline Amala & Amala Ekadasi & $\begin{array}{l}11^{\text {th }} \text { day of Phalguna Sukla; people bathe with Amala twigs soaked in water } \\
\text { and also consume it; worship it along with Radha-Krishna. }\end{array}$ \\
\hline Amra or Mango & Amra-puspa Bhaksana Vrata & a $1^{\text {st }}$ day of Chaitra Sukla; people consume mango blossoms and worship Kamadeva. \\
\hline Asoka & Asoka Pratipada & $\begin{array}{l}1^{\text {st }} \text { day of Chaitra Shukla; only women worship the Tree; they also observe fast } \\
\text { seeking longevity. }\end{array}$ \\
\hline Bakula & Bakula Amavasya & Bakula flowers are offered to the manes, seeking their blessings. \\
\hline Vata or Bargad & Vata Savitri Vrata & $\begin{array}{l}\text { Jyestha Purnima or Amavasya day; having fasted for the three previous days, } \\
\text { married women worship the bagged tree by circumambulating, while tying the } \\
\text { sacred protective thread around the tree (raksa Sutra), and listen to the sacred } \\
\text { Savitri-Satyavan story; some women stay awake during the night before } \\
\text { completing the vow by feeding brahmins; in the western parts of India, } \\
\text { devout women observe this vow for five consecutive years after marriage. }\end{array}$ \\
\hline Bilva or Bel & Bilva Tri-ratri Vrata & $\begin{array}{l}\text { On Tuesday of Jyestha Purnima when the constellation is Jyestha, people worship } \\
\text { the bel tree for three consecutive nights as per Hemadri's injunctions in the Skanda } \\
\text { Purana; the vow comprises bath with water mixed with mustard seeds, partaking } \\
\text { of sacred sattvic food (havisyanna), adorning the tree with two pieces of red cloth } \\
\text { and placing the image of Uma-Mahesvara beneath it; Homa is performed with } \\
1008 \text { Bolivia leaves offered; Brahmins are fed. }\end{array}$ \\
\hline Bilva or Bel & Sravana Krisna Ekadasi & Involves the ceremonial offering of water to the bel tree. \\
\hline Bilva or Bel Bhadra & Shukla Chaturthi & Offering of trifoliate leaves of bel to Lord Ganesa. \\
\hline Bilva or Bel & Bilva Nimantrana & Asvina shukla sasthi; invoking the tree-goddess and worshipping the Devi. \\
\hline Bilva or Bel & Bilva Saptami & Asvina shukla saptami; a twig of bel with two fruits is offered to Devi. \\
\hline Bilva or Bel & Bilva Navami & Asvina shukla navami; bel leaves are offered to Lord Siva. \\
\hline $\begin{array}{l}\text { Karavira or Kaner } \\
\text { or Oleander } \\
\text { (Neriumindicum) }\end{array}$ & Karavira Vrata & $\begin{array}{l}\text { Jyestha shukla prathama tithi; kaner roots and branches are soaked in water } \\
\text { and adorned with a red cloth; offerings of seven cereals (sapta dhanya) and } \\
\text { fruits are made followed by fasting; Savitri, Satyabhama, and others performed } \\
\text { this vrata when they were in trouble. }\end{array}$ \\
\hline Kadali or Kela & Kadali Vrata & $\begin{array}{l}\text { Vaisakha, Magha or Kartika shukla chaturdasi; a banana tree is planted and } \\
\text { nurtured till it bears fruits; for the welfare of one's family, a person should } \\
\text { worship the tree with flowers, fruits, etc and circumambulate it. }\end{array}$ \\
\hline Kadali or Kela & Yaksa-samantaka & $\begin{array}{l}\text { Kadali Vrata: A golden banana tree is worshipped and offered to a brahmin } \\
\text { on any auspicious day. }\end{array}$ \\
\hline $\begin{array}{l}\text { Kevada or Screw Pine } \\
\text { (Panadanusodoratissimus) }\end{array}$ & Kevada Teej & $\begin{array}{l}\text { Bhadra shukla tritiya; As a way of soliciting unbroken married life, women } \\
\text { offer Kevada leaves to Lord Siva. }\end{array}$ \\
\hline Neem & Sitala Puja & $\begin{array}{l}\text { Chaitra navaratras; goddess Sitala who is said to reside in the neem tree is } \\
\text { propitiated ritually; Pat Gosain festival in Bengal means neem tree worship; } \\
\text { neem leaves are consumed on Vaisakha shukla saptami. }\end{array}$ \\
\hline
\end{tabular}

${ }^{6}$ http://bmtrainingprog.files.wordpress.com/2010/08/14-vandana-prapanna.pdf. accessed: 17.12.2011.

${ }^{7}$ http://www.salagram.net/Sacred-trees.html. accessed: 17.12.2011. 


\section{An Empirical Analysis Undertaken across the Western Ghats of India}

The Western Ghats (WG), region a valuable natural resource pool of the country, plays a crucial role in shaping the topography, climate pattern and the environmental system of the nation besides serving as a living laboratory of biodiversity. Several ecosystems within the Western Ghats landscape play a major role in connecting the ridge between the Western Ghats and Eastern Ghats, the two important flora and fauna regions of the country. Thus, the Western Ghats landscape is important not only for the people and biodiversity of the region, but also the social and ecological systems of the low lying areas as ecosystem services that flow from WG provide sustainability to the low landscapes of the entire peninsular India. Human beings derive many useful benefits from the existing biodiversity and it is a well known fact that a large number of people, directly or indirectly continuous to depend on forest resources for their livelihoods. Keeping in view the ever increasing population and an actual decrease in the forest areas, the Indian Government allocates funds under the Special Central Assistance (SCA) and Hilly Areas Development Programme for conserving and improving the present Western Ghats in Karnataka and other states. This programme, initially started during the Fifth Five Year Plan (1974-79), is still continuing. Across various plan periods, the focus of the program has varied. During the sixth plan, the watershed development programme was taken up, keeping in view the significance of ecological restoration and conservation of biodiversity of the region. Later, during the eighth five year plan, an integrated approach towards watershed development was initiated, while during the Ninth Five Year Plan, a greater emphasis was given to awareness creation, maintenance, preservation and restoration of biological diversity. Further, during the Tenth Five Year Plan, the emphasis was on the preservation of biodiversity and rejuvenation of the hill ecology with an equal emphasis given to economic activities and livelihood security of the inhabitants under the environmental conservation programme. The major conservation activities are depicted in Table 5.

The Western Ghats Development Programme is currently being implemented across 171 taluks covered by viz. Maharashtra (63 taluks), Karnataka (40 taluks), Kerala (32 taluks), Tamil Nadu (33 taluks) and Goa (3 taluks) with some of the original talukas sub-divided. In Karnataka WGDP has been implemented across all the 40 taluks coming under 11 districts of the state.

To conserve the natural resources, the Government has formed farmers organization called Executive Committee (E.C.) involving the local elected representatives, self help groups and user groups of the proposed watershed development area. The GP President happens to be President of E.C. with one watershed department official as Secretary of the E.C for facilitating the smooth functioning of the proposed watershed development activities with a view to for enhancing ecosystem services to the local people. This committee holds the sole responsibility of distributing WGDP benefits to the selected beneficiaries such as landless, labors, women groups, SC, ST communities, marginal farmers etc. (Figure 2).

\subsection{Green Cover Management}

The implementation of forest schemes such as agroforestry, social forestry and other forest activities is the second largest and important scheme under WGDP in Karnataka. The department of watershed in each district concerned executes monitor forestry works. Assistant Conservator of Forests (ACF) is the implementing officer in the Watershed Department and works under the guidance of District Watershed Development Officer (DWDO). Under this programme, the department raises plantations in the designed watershed areas and distributes seedlings to farmers to be planted in their farmyards and homestead lands. The department raises saplings

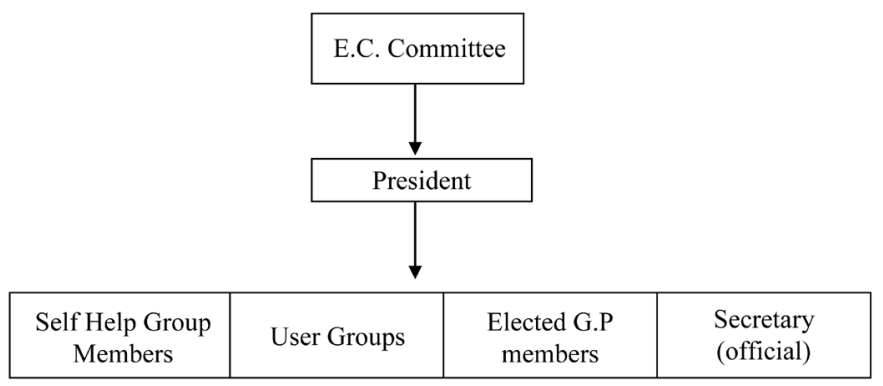

Figure 2. Ground level organizational chart for sustainable development of natural resources. 
Table 5. Conservation approaches for Western Ghats development.

\section{Watershed works}

1 Agriculture \& Soil Conservation works

2 Forestry

3 Agro forestry/Social Forestry

4 Spice Board

5 Horticulture

Foot bridges/Hanging

6 Bridges/vented

dam-cum-foot

bridges/PRED
The main objective of this scheme is to undertake soil conservation measures in watershed areas, and the activities covered under this scheme, include land development activities like levelling, bench terracing, land reshaping, amalgamation of paddy fields, land reclamation and contour bunding for increasing fertility and productive potential of agricultural fields; Water harvesting and erosion prevention structures like check dams, vented dams, nala bunding, boulder bunds and gully checks, diversion channels, filter strips for regulating the flow of water and diverting excess water.

This scheme focuses on conservation, preservation and development of biodiversity in the watershed area; activities under this scheme include the development of forest nurseries, conversion of grazing lands into forested areas; Planting of tree species on either side of roads, Mangroves cultivation, Planting of tree species like bamboo, azardecta indica etc on farm land bunds; Protection of forest areas and planting of tree species for green manure and afforestation.

This scheme aims at raising plantations in the beneficiaries land holdings coming under the watershed programme with a view to meeting the growing demand for timber, fuel, wood fodder etc., thereby reducing the pressure on the forest area. Planting of nurseries along roadsides, river and canal banks and on the village common lands comes under this scheme.

This scheme includes the distribution of I.P sets, sprinkler sets, construction of farm ponds and gravity irrigation in the beneficiaries lands coming under the watershed area.

The scheme serves the purpose of converting waste land into horticultural plots and adoption of rain fed crops on dry lands; taking up inter and mixed cropping activities.

The objective of this scheme is to provide rural connectivity to small habitations of Western Ghats. Under this scheme roads and foot bridges are provided for the people residing in the steep hilly terrains, (the Western Ghats region).

\section{D) Livelihood activities for asset-less persons}

Animal husbandry, Supply of Giriraja, birds/calfs/Development of small animals,

7 Supply of Sewing machines/Masonry, Fodder, Carpentry kits/Kitchen garden Animal health camp/ Fodder development

8 Livestock management including Goatry, Piggery.
This scheme includes development programmes for landless farmers coming under the watershed programme like artificial insemination for upgrading cattle, fodder cultivation on plots or farm lands, supply of carpentry kits and many other household kits for landless farmers; conducting of animal health camps and supplying of birds for the beneficiaries.

Income generating activities for landless farmers - development of piggery and Goatry for meat and fibre.

\section{E) Production system \& micro enterprises}

which are suitable for the local environment and plant the same accordingly for the prescribed year. Under this scheme, the department considers both public and private lands and supplies seedlings/plants to beneficiaries free of cost. The benefits accruing from the plantations during the harvest period are shared by farmers equitably. Views of the villagers/beneficiaries are taken into consideration by the department officials prior to planting in the watershed areas and public lands and are mainly done on bunds and banks of streams and rivers for arresting rain water and also for avoiding runoffs. More importantly, it is the forestry related activities that mainly characterize the ecological restoration besides facilitating development under WGDP in Karnataka. The government allots 20 per cent of the WGDP budget for promoting forest development related activities in the Western Ghats. However, it needs to undertake more activities to fulfill the actual needs.

\subsection{Critical Empirical Field Observations}

The analysis highlights the schemes and programmes that are performing well and also the ones which are not. There are some schemes which need very innovative methods of implementation so as to be more effective, while some others need to be re-worked in terms of their focus and resource allocation. There is also an urgent 
need for a change in the approach and attitude on the part of the forest department towards the local communities as well as the programmes and schemes keeping in view the significance of community participation. Although there have been attempts made from time to time to involve the local communities in many of the programmes like Special Development Plan, Greening of Urban Areas, Eco tourism, Raising of seedlings for public distribution, Development of degraded forest etc, the extent of their active participation leaves much to be desired. It is important to note that Participatory approaches for resource governance have proved to be effective in terms of yielding favorable results such as halting the degradation of environment in different parts of the world. An important issue which needs to be addressed is the burgeoning of the staffs at higher levels and the reverence of it at lower levels.

\subsection{Man, Animal and National Parks}

Bandipur National Park is rich in biodiversity and wild animal Species. There are two major issues related to the wildlife division; 1) Man-animal conflict; 2) Habitat improvement of these two issues, man-animal conflict is the major one because, a majority of the people (75\%) of the region have a negative attitude towards the park.

However the forest department has taken up some major steps towards reducing man-animal conflicts by putting up a solar fencing around the forest boundary and also by digging up deep trenches to stop the movement of animals into farm fields. Japan International Cooperation Agency is providing 30 per cent of the cost incurred for the solar fencing (Rs. 2 lakh per kilometer), across the $135 \mathrm{Sq}$. km boundary, but the Government is not providing the required annual maintenance cost of about Rs. 30,000/km.

The compensation amount given to farmers constitutes $1 / 10^{\text {th }}$ of their loss caused by wild animals, even as the forest officers feel that the compensation amount should be increased to $1 / 3^{\text {rd }}$ of the total cost incurred and that the timely release of such funds is necessary.

Habitat improvement is another essential aspect concerning this protected area. The luxuriant growth of Lantana species has occupied the maximum area (more than 60\%) of BNP. It is one of the major weeds that has invaded this forest ecosystem, replacing the habitat of the native vegetation cover. In view of this development, the Government has initiated a scheme called "Eradication of Lantana", but it is not being properly carried out because of an insufficient allocation of funds and focusing on smaller areas.

According to Divisional Conservator of Forest (DCF), approximately Rs. 25,000 - 30,000/Ha is required for Lantana removal in the national park, but the current allocation is very inadequate. The tremendous growth of Lantana is closing in on many corridors which the wild animals use for moving around. However, the challenge is that, within the framework of habitat improvement, the forest department has to provide food, water and shelter to wildlife. Lantana growth is a threat to the native vegetation cover leading to a reduction in grass availability for the wild herbivores. Therefore, the involvement of local people is the necessary in conservation and management of biodiversity of the region. However, the forest department has reported a relatively few number of cases of poaching, smuggling and hunting of wild animals due to the presence of strict rules and regulations.

Further, there should be a separate contingency grant/fund in place in case of any human or wildlife injury/ loss.

\subsection{Issues That Need to Focus}

There seems to be no proper cooperation and co-ordination between the forest department and other line departments with regard to forest management. The research wing of the forest department, is weak and hence, it should associate with other research organizations for better outputs. The policy implementation should be regionspecific with a better recruitment policy at all levels. As there are more personnel at the top and few at the ground level there is no balance observed in the execution of work. The critical suggestion based on observations includes the following and Figure 3 represents the better management process:

1) Quality Planting Material (QPM) should be planted.

2) Accountability and Transparency should be ensured at various levels.

3) Proper maintenance is required.

4) Computerization of records is essential.

5) Global Position System (GPS) should take a keen interest in monitoring the works handed over by the forest department.

6) There should be no irregular release of funds that affects the plantation activities right from germination to 


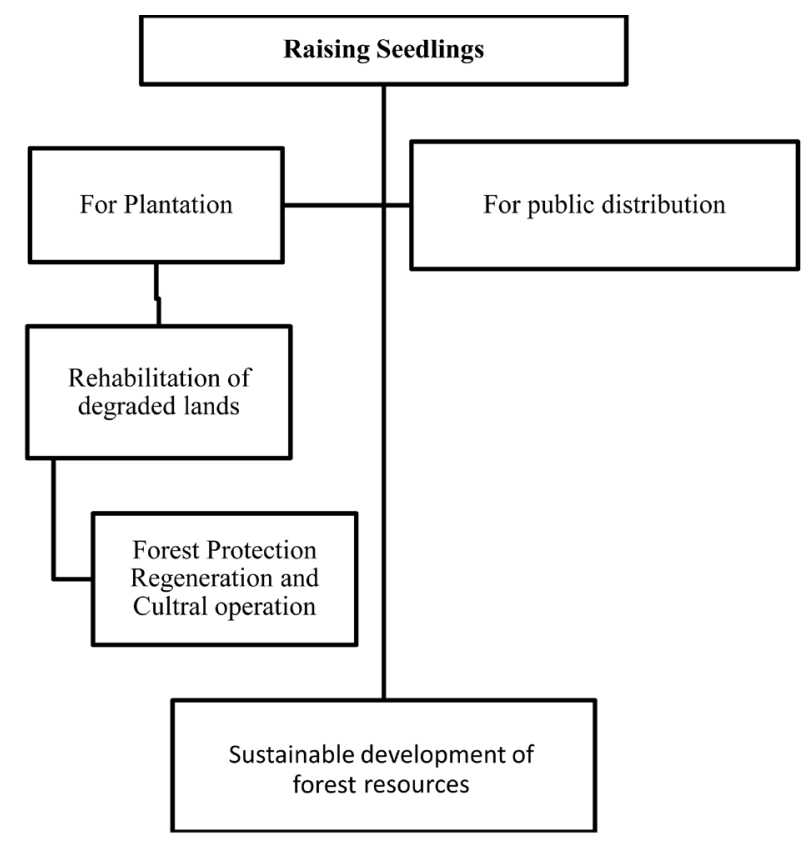

Figure 3. Sustainable approaches for resource conservation.

seedling transplantation stages.

7) For pre-monsoon period, activities like nursery development might be a problem due to irregular release of funds which can be avoided.

8) There is no timely tender process in place.

9) Inadequate staff at the field level.

10) The department should encourage villagers to form VFCs and the watchers should work under the guidance of VFCs.

11) Basic information should be given for forming VFCs, like how to conduct meetings, who should be involved in meetings and training programmes and benefits of forming VFCs.

12) Trainings should be given to villagers and VFCs regarding conservation and management of forest or plantations.

13) Protection should be provided by a committee consisting of members from the forest department and villages.

\section{Need to Rethink Policies with Regard to Development of Protected Areas}

Various studies support conservation oriented policies in respect of the protected areas as they constitute cornerstones in conserving biodiversity [8]-[11]. However, some significant research studies point out that a further debate is required concerning the process and relevance of establishing protected areas which tend to demean human existence [12]-[15]. A variety of external driving factors including climate change, have brought about a shift in terms of social and ecological processes across the landscapes protected for biodiversity conservation [11] [16]. Further, in view of the fact that these changing socio-economic and ecological processes are more visible in the protected areas Figure 4, it is necessary that agencies, managers, policy makers, scientists and the public do a rethink in terms of devising innovative policy responses for biodiversity conservation and sustainable socio-economic development. This is especially important in respect of the protected areas where people have been living in harmony with nature for centuries.

Thus, for effective implementation of the conservation policies, scientific and technological research should support the policy making processes. When science and policy differ, the outcome, in the form of communication, is often problematic [16]. The requirement is-that the scientific information is as per the requirements of policy demand and that it is easily accessible to policy makers and decision takers. On the other, policy makers and decision takers should formulate appropriate policy responses in such a way that it is easily understandable 


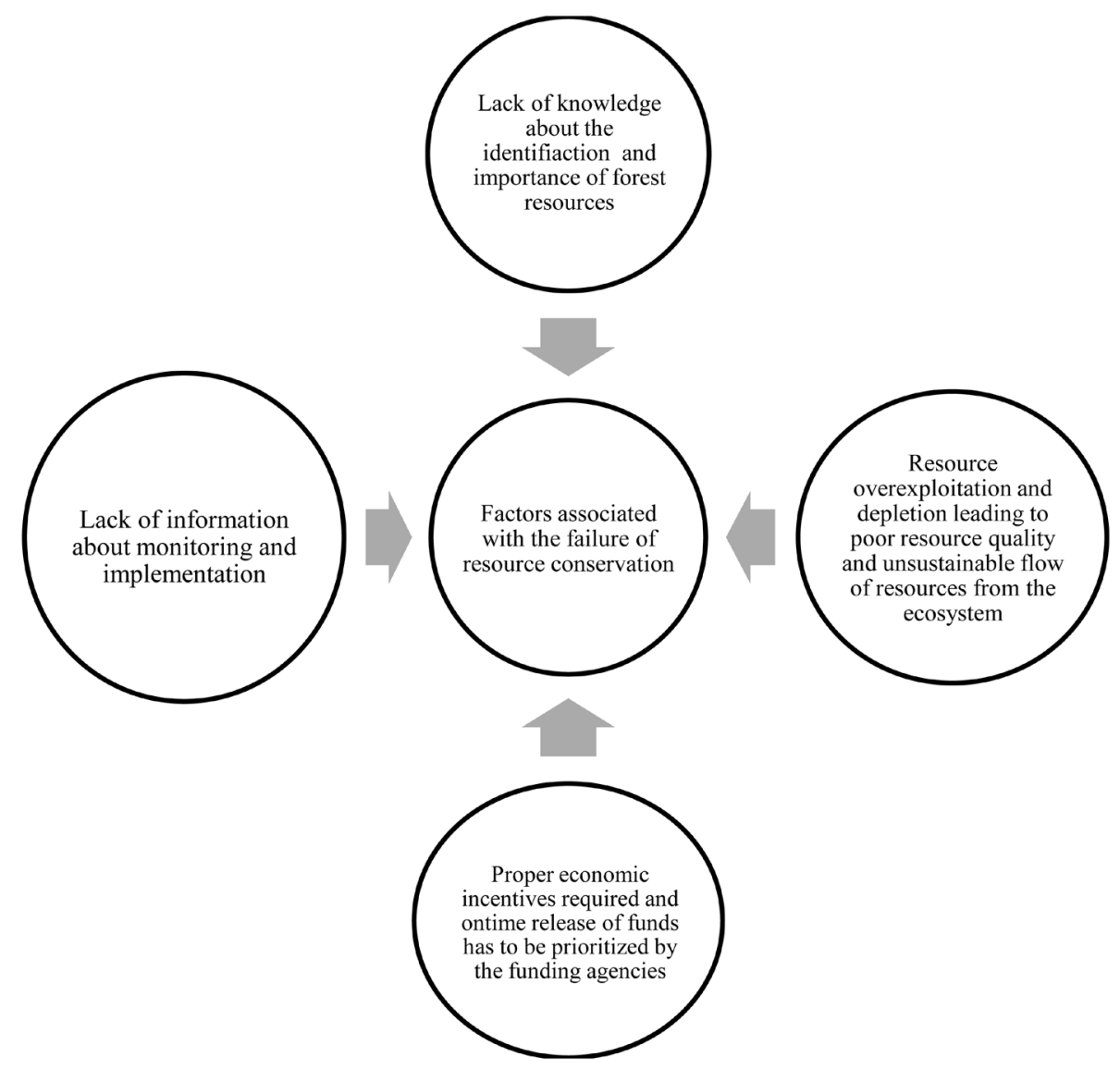

Figure 4. Factors responsible for resource conservation failure.

for researchers so as to be able to provide available scientific information based on their deliberations [17]. This approach could help evolve effective science-policy responses for protected area management (i.e. in terms of impact, causes, effects, adaptation, conservation and management of biodiversity) at local, regional, national and international levels.

\section{Contemporary Approaches for Resource Management}

The growing global concern for the conservation of natural resources has resulted in the formulation of longterm perspective plans. Forest resources facilitate the maintenance of ecological balance, biodiversity, enhancement of the quality of environment by checking soil erosion, water retention and conservation, regulation of water cycle, acting as carbon sinks which balance carbon dioxide and oxygen in the atmosphere and the greenhouse gas effects, etc.

Biodiversity and ecosystems are a natural basis ensuring sustainable resource use, including forestry, farms, renewable energy, urban land use, fisheries and other coastal \& marine resources [17]. There has been a growing awareness of the business impacts of biodiversity loss and degradation of ecosystems. Conservation measures that combine land development, land conservation, and revenue generation provide a functional protection for conserving resources. Further, conservation projects are created through a process of ecologically based planning and design, whereby planners assess a site's natural resources and environmental context and use this knowledge for conserving portions of the site with a high resource value while designing a development process that minimizes the environmental negative externalities [18].

Although conservation oriented projects appear to have a fair potential for protecting biodiversity and ecosystem services, there have been few attempts made to evaluate their actual conservation benefits. In practice, the success of such conservation projects is typically measured in terms of the percentage of the total site area set aside as a protected land, but this indicator does not explain whether a given site's conservation values are being 
protected functionally. Therefore, it is argued that traditional knowledge is very crucial to contemporary natural resource management and conservation.

\subsection{Socioeconomic Implications}

The development of the local economy, while managing Common Pool Resources (CPRs), has become an integral part of the sustainable development policy in many of the developing countries over the past few years [19]. This initiative has emerged largely due to a strong realization of disillusionment with the performance of the centralized management policy in terms of providing sufficient incentives to the resource users for managing the local resources on a sustainable basis. Participatory resource management is often seen as an appropriate solution to reducing rural poverty and resource degradation, while granting community property rights over the local level natural resources would ensure an equitable and sustainable use of environmental resources [19]. More precisely, when the responsibility of allocating natural resources for conservation is delegated to local organizations, communities tend to use these resources for the collective welfare of the community.

Poverty, property rights and the distributive consequences of community-based resource management are becoming increasingly a major subject of discourse with respect to the local level collective action. A long held perception is that common property resource appropriators can create and sustain the local management institutions for ensuring an equitable access to, and income from resource management. Further, CPR related literature claims that since poor people are heavily dependent on natural resources, they derive higher incomes from CPRs [19]. More importantly, there is a less attention given to the fact that a mere institutional change of resource management might not help certain sections of the community, especially the poor and marginalized people, as they are often the most vulnerable sections of the community.

\subsection{Innovativeness towards Resource Conservation}

An innovative community is not one founded to produce and distribute products invented by a single individual. An innovative community has the means to stimulate, nurture and develop innovation among its people. The lessons learned from open-source development can be transferred to other existing innovative user communities of physical products as well. Farmers in the developing countries possess quite a sophisticated knowledge of agriculture and natural resource management which is recognized as being more eco-friendly and sustainable (Singh, online). Indigenous Knowledge (IK) is dynamic, in terms of changing mechanisms of creativity and innovativeness and contact with other local through international knowledge systems. Indigenous Knowledge Systems (IKS) may appear simple to an outsider, but they represent mechanisms that ensure the minimal livelihoods for the local people mainly because the structure and content of traditional knowledge are intimately linked to the local bio-resources and ecosystems [20].

Most natural-resource planners recognize genetic diversity and its underlying processes as essential components of an ecosystem and species stability, adaptability and conservation, but there is rarely an explicit provision for the conservation of genetic diversity in management planning and decision-making [21]. The conservation of genetic diversity is essential for many reasons. Given the current worldwide pervasiveness of habitat fragmentation, integrating the conservation of essential ecosystem processes with human population needs is urgent [21]. There is a need for promoting social and economic infrastructure development to realize the potential benefits of the market economy, under natural resource policies that incorporate the environment as well as local people's rights and economies. There is a need for reforming and strengthening of forest governance and the forest-sector by way of ensuring a sustainable forest resource use and forest conservation through promoting modern scientific approaches Figure 5. Because, forest development with a mere industrial emphasis and a narrow-minded resource use, can further weaken the connection between local people and forests.

While every site is unique, challenges involved in managing the same tend to differ from country to country and even region to region or site to site [22]. Social and ecological dynamics and the human dependence on the capacity of ecosystems in terms of generating essential services and the vast importance of ecological feedbacks for societal development, suggest an interconnection between social and ecological systems. A social system includes economy, actors and institutions in mutual interactions [22]. More importantly, power, politics, knowledge, social differentiation, economic development, livelihood quality (often understood as both social and environmental), and ecological resilience have emerged of late particularly salient aspects of human-environmental issues. 


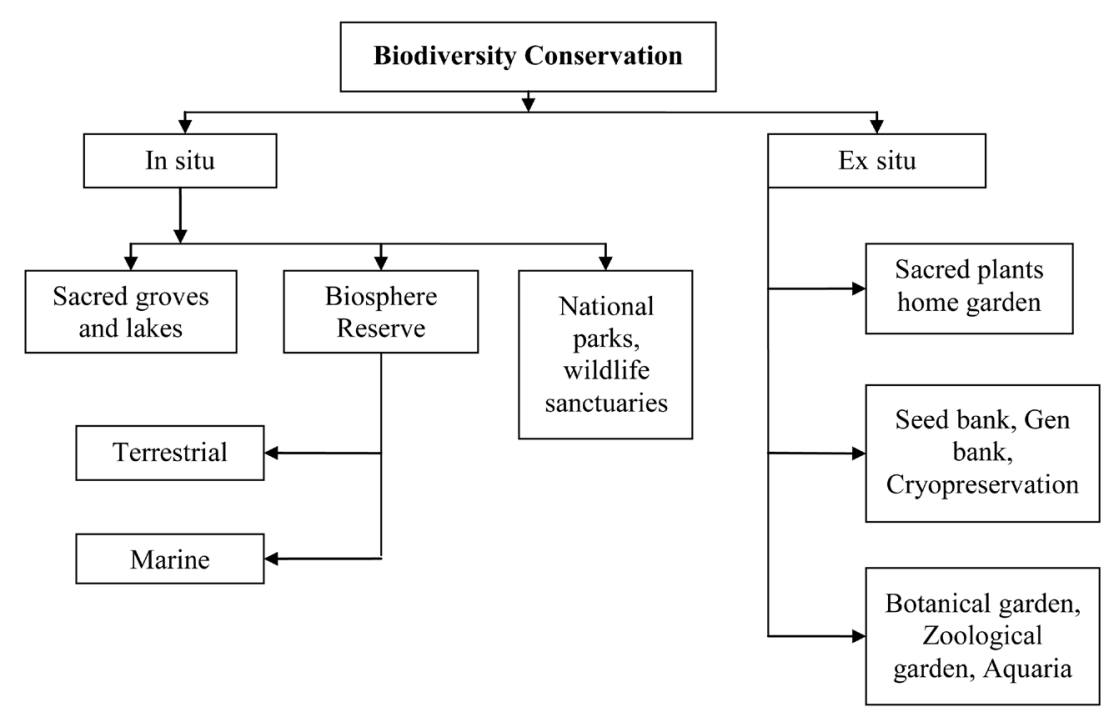

Source: http://www.tutorvista.com/content/biology/biology-iv/biodiversity/india-biodiversity-conservation.php (Accessed 19.03.2015).

Figure 5. Approaches for biodiversity conservation (in situ and ex situ).

\subsection{The Need: Integrated Natural Resource Management Policy}

The need of the hour and a possible solution, particularly in view of a possible threat looming large over the future generation, is to think of natural resources as one integrated piece of asset on this planet. These resources should be governed by uniform use policy, be it land, water or air or even forest or minerals. In fact, natural resource management with conservation and resource enhancement and preservation and pollution abatement as its primary goals, should be the focus of a new set of policies by the government. An integrated natural resource management policy can be a directive principle underlying the policy for states to administer with various departments Figure 6 and the Centre to monitor and evaluate the programmes. An umbrella legislation like the well-drafted EPA (Environmental Protection Act) 1986, can go a long way in making a thematic conservation strategy for resource utilization and regeneration possible. People need to be the focus of any such policy [23].

Fundamental changes, necessary for preventing a large scale destruction of the nations (and the world's) natural resources, can occur only if people could enjoy greater incentives so as to be able to rethink and reform their behavior towards the environment [23].

The failure to view natural resources and the environment as one whole entity can have far reaching adverse consequences. Ecology entails an interrelated existence of living beings and natural resources with environmental justice as the touching stone of resource conservation. Considering that resource conservation is a necessary condition for ensuring environmental justice, reorienting the legal regime towards this goal becomes significant in terms of policy and effects. The interlinkage between water (jal), soil (jameen) and forest (jungle), calls for a long-term plan for developing forests, stopping the expansion of deserts, conserving soil fertility and nurturing groundwater through rain water harvesting, especially for meeting the challenges of droughts. The lack of integrated approaches and definitive standards in this sphere allows different statutory bodies to adopt different criteria and policies while exercising overlapping controls with communication gaps so as to escape public accountability through mutual accusations [23].

Unless conservation and preservation become the main aim of policy-making, environment in general and resources in face a possible threat of extinction. Nature as a harmoniously unified entity, cannot tolerate a proverbial situation of "too many cooks spoiling the broth" [24].

\section{Conclusions}

This paper highlights the significance of natural resources and their utilization right from ancient to modern times in addition to an inalienable relationship between human beings and natural biodiversity. NRM refers to the management of natural resources such as land, water, soil, plants and animals, with a specific focus on how 


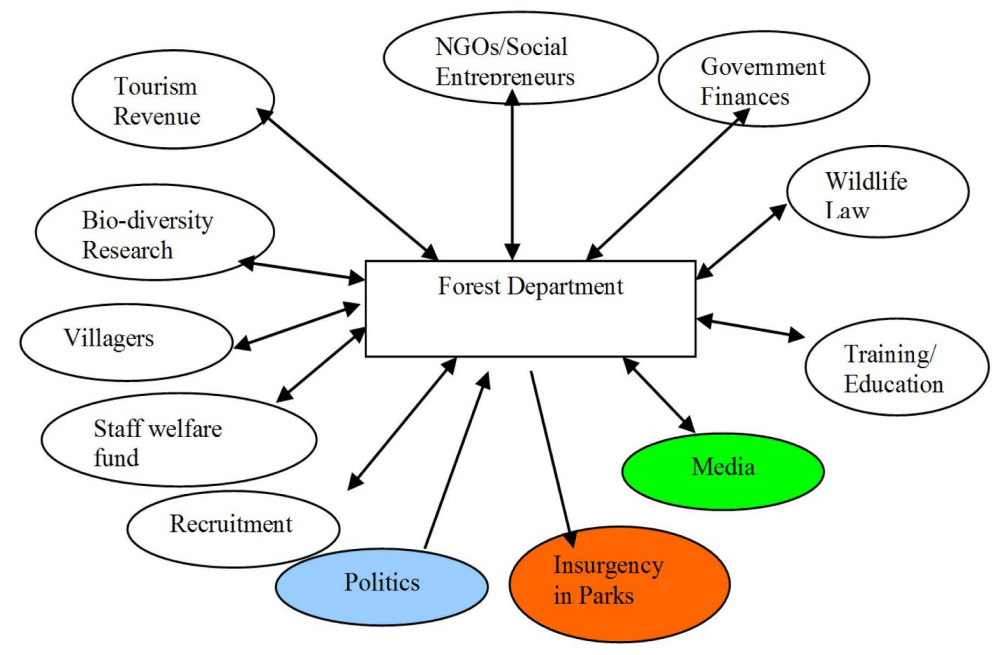

Source: www.iimahd.ernet.in/egov/ifip/susan-sharma.htm (Accessed 20.06.2014).

Figure 6. Approaches for biodiversity conservation (in situ and ex situ).

management affects the overall quality of life. Indigenous people happen to be the carriers of ancestral knowledge and wisdom regarding biodiversity. Their active participation in biodiversity conservation programs is essential for resource management to be more effective and cost-efficient. A comprehensive NRM approach is very critical to human survival and prosperity. Forests worldwide cover around 3.9 billion hectares, while the existing forest resources are divided into six categories globally, namely, Moist Tropical, Montane Sub Tropical, Dry Tropical, Montane Temperate Forests, Sub Alpine and Alpine.

Under diverse natural conditions, over a billion people in rural and urban areas live in harmony under a democratic system in India. However, the loss and fragmentation of natural habitats invariably affect all animal and plant species. The predominant causes underlying the declining forest cover are over-exploitation, overgrazing, encroachments, unsustainable practices, forest fires, and non eco-friendly development projects in the forested areas. Forest resources help protect ecological systems besides enhancing the quality of environment by way of controlling soil erosion and water retention. But, increasing population and commercial demand for wood have dented the natural forest cover nurtured by our ancestors.

Considering that local knowledge is no longer receiving its due attention in modern India, the loss of natural biodiversity has doubled with conservation becoming much more challenging. Along with science, local technologies and people's knowledge regarding ethno forestry have an important role to play in biodiversity conservation and sustainability. A balance between local and formal institutions can result in empowerment, security and opportunities for local people. Also equity of knowledge provides an opportunity for local people to participate in the management of local resources with global implications.

Conservation management is created through a process of ecologically based planning and design, whereby planners assess the state of natural resources in the environmental context and use their knowledge for conservation to minimize the environmental impacts.

Participatory resource management is often seen as an appropriate approach to reducing rural poverty and resource degradation. A long held perception is that common property resource appropriators can create local management institutions that can ensure an equitable access to the locally based natural resources. India was one of the first nations in the world to have established a professional forest service system under the provisions of the Forest Act 1865. The first forest policy of 1894 had upheld the right of the state to an exclusive control over the forest resources.

There is a need for promoting social and economic infrastructure development for realizing the potential benefits of the market economy through natural resource policies that incorporate the environment as well as local people's rights and local economies. Farmers in the developing countries possess a fairly sophisticated knowledge of agriculture and natural resource management which is recognized as being more eco-friendly and sustainable. Reforming and strengthening of forest governance and the forest industry sector is essential for ensuring a sustainable forest resource use and forest conservation through promoting the modernization of forest conservation. Because, development with an industrial emphasis coupled with a reckless resource use can further 
weaken the interrelationship between the local people and forest resources.

Since ecology is all about an interrelated existence of living beings and natural resources, an integrated natural resource management policy can be an ideal directive principle of the State policy for states to administer and the Centre to monitor and evaluate.

\section{References}

[1] Sobrevila, C. (2008) The Role of Indigenous Peoples in Biodiversity Conservation: The Natural but Often Forgotten Partners. The World Bank, Washington DC.

[2] Aiyangar, K.S. (1941) Ancient India and South Indian History \& Culture: Papers on Indian History and Culture; India to A.D. 1300. Oriental Book Agency.

[3] Bimala, C.L. (1888) Historical Geography of Ancient India. Societe Asiatique De Paris France.

[4] Hunter, W.W. (1883) A Brief History of the Indian People. 3rd Edition, Trubner and Company, London.

[5] Karthikeya, S. (2007) What Are the Threats to Biodiversity. Centre for Education and Environment. http://www.vigyanprasar.gov.in/Radioserials/Threat_to_biodiversity_-_draft_paper.pdf

[6] Glikson, A. (2012) Is Another Mass Extinction Event on the Way? The Conservation. http://theconversation.com/is-another-mass-extinction-event-on-the-way-5397

[7] Gulati, S.C. and Suresh, S. (online) Population Pressure and Deforestation in Institute of Economic Growth, New Delhi. http://www.corecentre.co.in/database/docs/docfiles/population_pressure.pdf

[8] Baron, J.S. (2004) Research in National Parks. Ecological Applications, 14, 3-4. http://dx.doi.org/10.1890/03-5174

[9] Zeng, H., Daniel, Z.S. and Wu, X.B. (2005) Human Disturbance on Landscapes in Protected Areas: A Case Study of Wolong Nature Reserve. Ecological Research, 20, 487-496. http://dx.doi.org/10.1007/s11284-005-0065-6

[10] Ninan, K.N., Jyothis, S., Babu, P. and Ramakrishnappa, V. (2007) The Economics of Biodiversity Conservation-Valuation in Tropical Forest Ecosystems. Earthscan Publications, London.

[11] Baron, J.S., Gunderson, L., Allen, C.D., Fleishman, E., McKenzie, D., Meyerson, L.A., Oropeza, J. and Stephenson, N. (2009) Option for National Parks and Reserves for Adapting to Climate Change. Environmental Management, 44, 1033-1042. http://dx.doi.org/10.1007/s00267-009-9296-6

[12] Kothari, A., Suri, S. and Singh, N. (1995) People and Protected Areas. Rethinking Conservation in India. The Ecologist, 25, 88-194.

[13] Kothari, A., Pathak, N., Anuradha, R.V. and Taneja, B. (Eds.) (1998) Communities and Conservation: Natural resource management in South and Central Asia. Sage Publications, New Delhi.

[14] Bruner, A.G., Gullison, R.E., Rice, R.E. and da Fonesca, G.A.B. (2001) Effectiveness of Parks in Protecting Tropical Biodiversity. Science, 291, 125-128. http://dx.doi.org/10.1126/science.291.5501.125

[15] Lasgorceix, A. and Kothari, A. (2009) Displacement and Relocation of Protected Areas: A Synthesis and Analysis of Case Studies. Economic \& Political Weekly, 49, 37-47.

[16] Klabbers, J.H.G., Swart, R.J., Janssen, R., Vellinga, P. and Van Ulden, A.P. (1996) Climate Science and Climate Policy: Improving the Science/Policy Interface. Mitigation and Adaptation Strategies for Global Change, 1, 73-93. http://dx.doi.org/10.1007/BF00625616

[17] Van den Hove, S. (2007) A Rationale for Science-Policy Interfaces. Future, 39, 807-826. http://dx.doi.org/10.1016/j.futures.2006.12.004

[18] Jeffrey, C.M., Lassoie, P.J. and Bedford, L.B. (2007) Conserving Biodiversity and Ecosystem Function through Limited Development: An Empirical Evaluation. Conservation Biology, 22, 70-79.

[19] Adhikari, B. (2002) Property Rights and Natural Resource: Socio Economics Heterogeneity and Distributional Implications of Common Property Resource and Management. EEE Working Papers Series-No. 3, University of York, UK.

[20] David R. Downes, D.R. and Laird, S.A. (1999) Community Registries of Biodiversity Related Knowledge: The Role of Intellectual Property in Managing Access and Benefit. http://www.ciel.org/Publications/CommunityRegistries.pdf

[21] Boshier, D. and Amaral, W. (2004) Threats to Forest Ecosystems and Challenges for the Conservations and Sustainable Use of Forest Genetic Resources. In: Vinceti, B., Amaral, W. and Meilleur, B., Eds., Challenges in Managing Forest Genetic Resource for Livelihoods: Examples from Argentina and Brazil, International Plant Genetic Resources Institute, Rome.

[22] Shioya, M. (online) Socio-Ecological Resilience and Adaptive Governance towards Sustainable Resource Management (Case Studies from Malaysia and Japan). http://umconference.um.edu.my/upload/163-1/Paper\%20122.pdf

[23] Bhat, S. (2010) Natural Resources Conservation Law. Sage Publications Pvt. Ltd, New Delhi, 13.

[24] Ball, S. and Bell, S. (1994) Environmental Law. 2nd Edition, Universal Book Traders, New Delhi, 254. 